\title{
The same difference: Jesusa Palancares and Poppie Nongena's testimonies of oppression
}

\author{
Marita Wenzel \\ Department of English \\ Potchefstroom University for CHE \\ POTCHEFSTROOM
}

\begin{abstract}
Two women's texts from postcoloniall countries, Mexico and South Africa, on different continents show surprising correspondences in subject matter and style. Elena Poniatowska's Hasta no verte Jesús mío (Till I meet you, my Jesus) and Elsa Joubert's Die swerfjare van Poppie Nongena (The journey of Poppie Nongena) examples of testimonial writing, both address issues of gender and politics in an innovative way. They combine autobiography and biography to render a dramatic account of social injustice despite their disparate backgrounds'cultures and subtle differences in style. In comparison, the texts not only affirm the validity of women's writing and contribute to its enrichment, but also constitute a valuable contribution towards the formulation of a general feminist aesthetics. In fact, they illustrate conclusively that comparative literature fulfils a vital function in the exploration and interpretation of women's literature from different cultures.
\end{abstract}

\section{Gender and difference}

Whereas the traditional perception of difference as a binary opposition ${ }^{2}$ undermined the significance of underlying relations between concepts, the validity of

1 Postcolonial denotes the process of decolonization taking place in countries formerly under colonial rule and does not imply a final state of liberation - if such a concept is possible.

2 In kecping with the postmodernist concept of the dissolution of rigid boundarics, several feminist critics (Haggis, 1990:114; Meesc, 1990:100; Newton \& Rosenfelt, 1985:xxvii; The Personal narratives group, 1989:19; Scott, 1988:44) have claimed that difference should be seen in a relational sense, that is, as difference in degrec which would imply the accommodation of difference instcad of its climination. 
traditional power structures is questioned in the postmodernist context where difference is perceived as a relational concept which no longer implies exclusivity. Consequently, the initial cultural discrimination, or difference, committed in the name of imperialism has been revised and attempts made to redress the cultural imbalance. In this endeavour, women have also been recognized as an oppressed and marginalized group, and have become aligned to colonialism/ racism. Because of this association, their cause has unfortunately, in many instances, been subsumed under a general politics of liberation. ${ }^{3}$ In principle this seems quite justifiable, but in practice feminist issues have been neglected because their quest for social equality has still not been sufficiently addressed or resolved by political organizations. This is evident in the persistent concern with oppression as expressed in women's writing during the last two decades.

To avoid a repetition of the marginalization of women's grievances, and to address gender discrimination constructively, it is necessary to distinguish it from other forms of oppression. However, it should also be explored within its historical context. What a number of women have attempted to express in writing is their right to be accommodated on account of, and despite their differences. Consequently, they have relinquished their former aggressive stance and have appropriated a more subtle approach in an attempt to counter and expose dominant ideological structures of power which manifest a deliberate ignorance of the 'other' dimension of experience.

As difference not only exists between genders and cultures but within sexes, classes, and languages, I would suggest that women concede differences among themselves - but also acknowledge the correspondences in their situations. In this respect, Latin America and South Africa share a colonial heritage, authoritarian regimes and male-dominated, patriarchal societies where the indigenous women bear a double burden of oppression. Thus women's oppression can be regarded as a cause of common concern or a "commonality" which Barry (1989: 572) correctly identifies as a crucial prerequisite for women's social advancement because:

Whenever differences are emphasized without first recognizing collectivity, commonality, and unity among women, gender power is depoliticized. In other words, we are asked to suspend our consciousness of the structure of domination - its dyadic formation - to find or impose differences among women, which are actually the consequence of dyadic domination.

3 Meese (1990:65), for instance, dismisses feminism as an emanation of imperialism and accuses Nadine Gordimer of a "misdirected segregation of feminism from political resistance", thereby implying that Gordimer deems feminism as inferior to the political struggle for liberation. 
Although contemporary women's literature is then characterized by a subversive strategy, it cannot be claimed as the 'trade mark' of feminist literature because, as Felski (1989:34) points out, it reflects a postmodemist approach common to most contemporary literature. However, it should be kept in mind that women's writing would require an alternative reading strategy to reveal the full complement of meaning. Within this context, a comparative approach also introduces new dimensions of interpretation which contribute to an understanding of disparities in race, culture and gender.

In this article I propose to point out disparities and correlations in subject matter and style in the texts of Hasta no verte Jesús mio (1984) by the Mexican novelist Elena Poniatowska, and Die swerfjare van Poppie Nongena (1978) by the South African Elsa Joubert, which would characterize these works as examples of testimonial literature and illustrate their significance as testimonies of oppression within their particular, local socio-historical contexts.

The texts represent a combination of autobiography and biography - (auto)biography ${ }^{4}$ - because the protagonists (Jesusa and Poppie) are historical personages from marginalized postcolonial societies who are interviewed/interpreted by women from European cultures. These texts represent a more subtle form of feminist assertion than testimonial writing which is accusatory in tone. ${ }^{5}$

\section{Writing as experience}

The popularity of autobiographical writing in contemporary literature and in particular in women's writing, seems a natural consequence of a social and historical condition. In fact, López González et al., (1988:14) regards it as a manifestation of an attempt to integrate the individual and personal into the social and the collective; to define personal and social identity. The writing of Rigoberta

4 Bloom (1991:12) coins a similar concept which she calls "auto/bio/history" and describes it as "the close collaboration between the author of an autobiographical document and the scholar who completes the original text with a complementary and equivalent text of her own". The two authors are interdependent and their contributions are symbiotically integrated (Bloom, 1991:13).

5 Testimonial writing can be described as the expression of personal experience in denunciation of oppression or, presenting the experience of a people through an individual who represents the collective consciousness (Bamet, 1986a:288). This definition which closcly corrclates with Bloom's (1991:13) definition of auto bio history, is illustrated in the testimonics of ordinary working women such as Rigoberta Menchu and Domitila Barrios de Chungara who denounce the system through an account of their personal experience. 
Menchu (1985) illustrates how the personal is expressed in terms of the social. ${ }^{6}$ Her testimony breaks the silence ${ }^{7}$ to define the personal in terms of the collective, whereas South African women such as Ellen Kuzwayo (1987) and Phyllis Ntantala (1992) have exposed and immortalized the injustices and effects of apartheid in autobiographies, but have not indicated a sense of solidarity as women. ${ }^{8}$

\section{Women and (auto)biography}

Friedman (1988:34) claims that the main difference between traditional and women's autobiographies lies in the concept of the autobiographical self. Whereas the former stresses individualism, the latter aspires to the individual's interdependence with the collective and should be read as an attempt to create the self in relation to others (Friedman, 1988:56). Barry (1989) in fact, identifies biographical writing as the ideal vehicle for expressing the progression from the personal to the political in women's experience/subjectivity because as she claims $(1989: 561)$, it "can become a study of social interactions". She indicates that such an approach

... is meant to collapse the dissociation of personal life from work and politics, and it rejects the tradition in scholarship which dichotomizes political and social history as well as macro- and microsociology.

Apart from their autobiographical framework, both texts have facilitators or interpreters which characterize them as biographies. Despite subtle differences in style - the stronger, more overt presence of irony in Hasta no verte Jesús mio also identifies it as a picaresque novel - I would, however, suggest that both texts belong to testimonial literature. I have opted for an amalgamated form, (auto)biography, to denote this significant deviation in autobiographical style. ${ }^{9}$

6 Her account of social oppression includes the individual aspect which Friedman (1988:4344) perceives: "... many women's autobiographies create the female self by exploring her relation with a fully rendered Other".

7 A term used by Tillic Olsen (1980)

8 Latin American women are acutely aware of the therapeutic and cathartic value of testimonial literature: Allende testifics to historical events in her writing as a means of commemorating injustice so that a repetition of similar injustices could be avoided in future; Prada Oropeza (1986:16) interprets testimonial literature as the affirmation of a personal impression of reality as opposed to a contradictory/official onc, whilc Fernándcz Olmo (1981:75) views it as a literature of democratization.

9 According to Lejcunc (1975:36/38), autobiography is characterized by its referential character and an implicit correspondence between the author, protagonist and narrator 
The socio-political situation of both Jesusa and Poppie - who are based on actual historical figures - necessitates the services of facilitators to articulate their respective experiences effectively, partly because of their defective education and partly because of their failure to grasp the political and social significance of their respective dilemmas. The differences in socio-historical context between the facilitator and the interviewee could either be regarded as unbridgeable, relegating any attempt to record them as a presumptuous and patronizing act ${ }^{10}$ or, as a positive gesture towards intercultural understanding, viewing it as a complementary dimension of experience.

In keeping with the perception of difference as a relational concept, I would suggest that the additional nuances of interpretation introduced by the facilitator only create a different angle of interpretation which renders a more comprehensive understanding of experience. In her discussion of the work of the anthropologist Barbara Myerhoff, Riv-Ellen Prell (1989:255) points to an important factor in the interpretation of a life when she claims that

... Myerhoff argued that seeing oneself in the eye of the other is an essential core of human interaction. In her production of life histories, one is aware of the double gaze of both subjects. They were seen, and she was seen. That mutual respect and witnessing were as apparent in her relationships with subjects as in any normative social interaction. (My emphasis.)

This statement clarifies an important criticism usually directed at 'translated' or facilitated experience. Like Poniatowska, Joubert's interviewing of an historic victim of oppression from a different race and culture could incur criticism of presumption. However, she (Joubert, 1984:61) defends her gesture as a means of gaining valuable insight into the psyche and culture of another person when she states that

Writing the book brought me a kind of peace. It meant much to me to get to know the woman Poppie well, to be led into her life, step by step, to be introduced to a world that had been strange to me. I was the richer for it.

10 Margaret Lenta (1984:157) strongly rejects Ampic Coctzcc's criticism (1979:28-30) expressed in this vein when she states that

"No South African resident would deny the difficulty of achieving sympathetic understanding of a member of another racial group, but to condemn as presumptuous or useless efforts to do so is a despairing verdict on our predicament. It shows too an cxcessive preoccupation with race, as if it were the only factor which unites or scparates people. Elsa Joubert's response to the black woman's narration of her life is that of a woman and a sister. It is significant, I think, that Coctzcc's pronoun 'lic' ignores the possibility that their shared womanhood could form an important link between the author and her subject." 
Her assertion is significant in several respects: it not only promotes cultural understanding and implies a broadened perspective but it "breaks the silence" (Lenta, 1984:147) of the oppressed, and it implies a bond of sisterhood despite differences in culture and race.

Barnet (1986a:299-300) does not regard the difference between the facilitator and the interviewee as an obstacle because he maintains that taking up position with the informant in trying to understand his point of view does not imply agreement with his stance, but should rather be seen as an act of engaging in a dialogue with the period. This perception not only emphasizes the crucial significance of context in any interpretation, but also implies an awareness of an appropriate reading strategy/approach. Both Poniatowska and Joubert wish to speak for the oppressed, to expose their plight and claim social responsibility for them. They subscribe to Barnet's (1986b:313) assertion that "Tenemos que ser la conciencia de nuestra cultura, el alma y la voz de "los hombres sin historia"."."

\section{The dual perspective: irony as corrective}

The risk that facilitation could result in either the distortion/misinterpretation 12 or over-simplification of facts creates an awareness of the narrow margin separating fact and fiction. Any imposition of order or act of selection implies a creative impulse to interpret reality. When a person in a more privileged position, such as either Poniatowska or Joubert, feels bound to relate these experiences and consequently acts as 'interpreter' to order and reconstruct experience, she inevitably informs the text with an additional dimension of meaning not previously apprehended by the subject of the tale - thus creating fiction and irony. For instance, although Jesusa's views on life are tinged with the cynicism of experience, she seems to accept that certain injustices are related to her condition as a woman. She relates the conditions of her marriage with resignation when she claims that "forzosamente el oficial se casó conmigo, pero no por mi voluntad ... Qué les interesa a los soldados el consentimiento de una mujer? Quisiera uno o no quisiera". 13 Consequently, Jesusa deduces that it is better to be a man than a

11 Translated: We have to be the conscience of our culture, the spirit and the voice of the people without history"

12 Fernández Olmo (1981:72) correctly points out that a clash in idcology' could lead to the distortion of facts; yct 1 belicve that showing an interest in a different idcology implies tolerance in attitude.

13 Translation: ' the official marricd me by force, but not with my consent. What do soldicrs carc about a woman's consent" They cither like one or they don " $t$. 
woman and does not for one moment contemplate that her situation might be rectified (Poniatowska, 1984:181).

Poppie is also resigned to the fact that she is dependent on the whims of a white official to have her work permit extended and she never questions the negation of her rights as an individual. To compound the injustice of the situation, she is classified according to her husband's ethnicity and consequently denied any rights to her status as a coloured and as a woman (Joubert, 1978:116). Consequently, the system remains unchallenged and it is this aspect which the mediator, on account of her privileged experience and her status as a woman, perceives as an avenue worth exploring and elucidating. Dorfman (1986:170) regards this task of facilitating/editing as a positive contribution to testimonial literature, because the facilitator/editor is uninvolved and therefore more critical and able to unite disparate perspectives and fragmented impressions into a meaningful text.

The presence of irony in both Hasta no verte Jesu's mio and Poppie Nongena, also attributes these texts with an additional dimension of meaning which transcends the direct statement of the autobiography and the openly accusatory tone of the testimonial. Dorfman (1986:187) specifically calls attention to the function of humour expressed through irony in testimonial literature. He claims that retrospection provides a means of survival (Dorfman, 1986:196) because it implies the interpretation of experience. I would propose that irony transmutes a personal experience into a political one, thereby creating a perspective which transcends individual experience and attains meaning for the collective. The testimonial is then intended for the collective to lean from individual experience.

This situation is illustrated in Die swerfjare van Poppie Nongena by Elsa Joubert and Hasta no verte Jesús mio by Elena Poniatowska, which are both seen as personal but politically significant texts. In her rendition of Poppie Nongena's life, Elsa Joubert acts as an observer and she establishes connections between seemingly unrelated incidents in Poppie's life which spell oppression without naming it. ${ }^{14}$

The 'I' protagonist in testimonial literature performs a triple role as witness, actor and judge (Jara \& Vidal, 1986:1). This disparity in perspective informs the text with qualities of objectivity, de-heroization and the alienation of individuality

14 Margaret Lenta (1984:151) also notes the ironic edge inherent in Poppic's situation

"Joubert is obviously conscious throughout the novel that her readers must understand that Poppic, like all other women in her predicament, is a woman who in normal circumstances would be compelled to remain silent partly becausc she understands only partially and gradually her own experience and rarely if ever relates it to political and social events in the country as a whole." 
(Dorfman, 1986:183). While Lenta (1984:148) perceives Joubert's use of the third person narrator as a strategy to avoid the monotony of direct reportage and to perceive the underlying pattern of events, it should also be identified with the testimonial - and almost picaresque - character of the text.

\section{The woman as subject: personal and/as political}

Barry (1989:569) is very aware of the inherent political intent of women's writing when she points out that

When intentionality is marked by consciousness, women's subjectivity is political. To the extent that women reclaim their history through their own intentionality, their history will be socially constructed and self-determined. In the best sense biography should be a profound interaction of the two the self and her history in the widest possible sense for which it can be reconstructed

The two texts under discussion manifest a consciousness of women's subjugation within the political context of their respective countries. As testimonial literature derives from a Latin American context, I shall use Hasta no verte Jesús mio as a 'master text' and refer to Poppie Nongena in counterpoint.

\subsection{Poniatowska's Jesusa}

As I pointed out above, female identity is closely interwoven with social identity and when Poniatowska gives voice to Jesusa and her particular account of oppression, ${ }^{15}$ she also launches an indictment of Mexican society and its disregard for women's rights. As a person, Jesusa can testify to male abuse and social marginalization and yet her indomitable spirit ${ }^{16}$ refuses to bow before tradition. Her views on men are clearly expressed when she claims that "Para ser

15 Jesusa is an illiterate Mexican peasant woman who grows up without a mother in a poor and unstable environment. Condemned to a peripatetic cxistence by her father's constant scarch for work, she suffers under her various 'stepmothers' and is coerecd into a marriage against her will. Her husband is a cowardly soldier who treats her brutally. When her stoic endurance finally comes to an end, she kills her husband and roams from place to place doing any job she can find. When Poniatowska finds her, she is a laundress, old and wom out from hard labour. She has become cynical of socicty and has taken recoursc to reincarnation as the only explanation for her carthly existence

16 As Lemaittre (1985:751) obscrves, Jesusa is onc of those women who "no sc dejaron dominar por nuestra socicdad patriarcal, aun cuando hayan sido victimas de una socicdad clasista". Translated "who do not allow patriarchal socicty to dominate them even when they have been the victims of a class-conscious society. 
malo el hombre, lo mismo es extranjero que mexicano. Todos pegan igual" (Poniatowska, 1984:168). ${ }^{17}$

A notable characteristic of Jesusa, commented on by various critics (Fernández Olmo, 1981:72; Jorgensen, 1988:112; Roses, 1981/82:60), is her nonconformity to the image of the female stereotype usually represented in literature - in fact she inclines towards the anti-heroine. Hancock (1983:353) regards her as "a step toward the delineation of a new female image or role model" because instead of displaying traits of submission and passivity, she shows preference for masculine characteristics intimating a more androgynous and defiant attitude. This becomes evident when she accompanies her husband to war dressed as a man (Poniatowska, 1984:107)

Lemaître (1985:755) attributes Jesusa's sense of independence and freedom to her upbringing. Due to the death of her mother early in her young life, Jesusa identifies with her father and relies on him to be a role model. Furthermore, due to her illiteracy and peasant background of poverty, Jesusa is relegated to the periphery of society. Constrained by her plight, she leads an itinerant existence which is further characterized by political unrest and authoritarian regimes. In fact, she is the epitome of how culture conditions perceptions of gender. LagosPope (1990:251) is quite clear about Poniatowska's indictment of the patriarchal and class systems and she points out that despite Jesusa's apparent difference from the general women of her class she also exhibits, to a large extent, the feelings of impotence and frustration experienced by most women. In this respect, her personal testimonial assumes universal implications.

Therefore, although Jesusa remains a character in her own right she also represents the plight of women and other marginalized people to the same extent that Tess of the D'Urbervilles (Hardy, 1978) is a tragic figure as a person but becomes representative of womankind in general. Thus the use of the testimonial mode enables the author to gain the empathy of the reader and yet, at the same time, to criticize society.

By enabling Jesusa to break the silence of her doubly marginalized existence, as a woman and as a member of a marginalized society (workers), Poniatowska provides her with a means of restoring her faith in herself as a person/individual - a motivation for expressing herself in writing - whose experience merits attention and as a member of society, thereby making a political statement for women and minorities.

17 Translation:

'Men are bad, whether they are forcigners or Mexicans. They all beat you. 
In assessing two contrasting stances on female experience in Hasta no verte Jesús mio, Hancock's concept of Jesusa as a liberated woman and Tatum's concept of Jesusa as a victim of circumstance respectively, Jorgensen (1988:112) points out that it is exactly this tension between new and traditional values which constitutes the significance of the text. In fact, it is the concept of change which Hancock (1983:354) identifies as a recurrent motif in the text, which is both criticized and exemplified by Jesusa. She is a rebel without being a revolutionary because she resists oppression in all forms "para realizarse como individuo" 18 (Jorgensen, 1988:112) and yet she is forced to conform to social values. It is this aspect which finds resonance in the picaresque strain which has surfaced in texts by Isabel Allende and Nadine Gordimer. ${ }^{19}$

It is clear, however, that both Jesusa - the protagonist - and Poniatowska - the author - subvert male authority to assert their female independence: Jesusa by assuming control of her life (Kushigian, 1987:676) and Poniatowska by inscribing Jesusa's life as a testimony to abuse.

\subsection{Joubert's Poppie}

Although Poppie is represented as an individual with a potential for love and caring, ${ }^{20}$ she also experiences the typical suffering and the same hardships as the rest of her race and gender (Lenta, 1984:151). Lenta (1984:149) also perceives her as a representative of a woman-centred culture which seems to have developed in postcolonial countries where colonial powers have debilitated black male authority and responsibility has consequently shifted to the women. Interestingly enough, this reversal of authority is often the cause for the abuse of black women by their men. Both Poppie and Jesusa display an inordinate amount of courage and endurance against the onslaughts of adversity, qualities which are characteristic of women as a marginalized group.

In a similar vein to Allende, Lenta asserts that by maintaining the silence, women only perpetuate their own suffering. She (Lenta, 1984:147) claims:

One of the strongest suggestions implicit in the book is that it is because women like Poppie cannot speak to the world, indeed, often cannot plead their cause effectively before the minor officials who are their immediate oppressors, that they continue to suffer injustice.

18 Translated, it means 'to attain sclf-rcalization as an individual".

19 Sec Wenzel (1993:49) on Gordimer's rendition of the picaresque in $A$ Sport of Nature (1987) and the reference to Allende's Lva luna as (1989) a picaresque novel

20 It is exactly this characteristic of Poppic which prevents her from attaining picara status 
In her discussion of Elena Poniatowska's work, Starcevik (1982:65) claims that silent complicity is also a transgression and thus emphasizes the value of testimonial literature which provides a challenge "to a populace that may be unaware and to a leadership that is deliberately silent". Joubert seems to execute the same function within the South African scene. ${ }^{21}$

Joubert demonstrates how Poppie's goodwill is slowly eroded by social indifference to her plight, infecting her with a similar attitude of indifference. Her fighting spirit finally concedes defeat and Poppie passes into a kind of apathy, a second more profound silence which Lenta (1984:156) describes as follows:

Her silence from this moment will be that of an individual who has no wish to communicate with the world, who no longer believes that she can do so, rather than that of a woman who lacks information of facility in written language.

As Lenta (1984:152) also points out, Poppie's unawareness of the irony of her situation causes the text to be devoid of any propagandistic tone. She does not indulge in analytical reflection but relies on sensory experience .

However, it must be stressed that the apathy she finally experiences is not a resignation to authoritarian structures but rather resignation to the inevitability of the revolution. This stance can clearly perceived in her final thoughts:

As die Here gewil het dat Jakkie moet gaan, moes hy gaan, dink sy. En as my kinders in die ding gesleep moes worde, dan is dit waartoe hulle gebore is. En wie kan uit hulle pad neem dit waarvoor hulle gebore is? (Joubert, 1978:276.)

Van der Merwe (1992:72) points out this deceptive quality by claiming that "waarin sy nou berus, is nie meer in die onderdrukking van die wetgewers nie, maar in die onvermydelikheid van die opstand". It is left to the reader to make the necessary ironical connections.

The individual's constant oppression and marginalization either invokes a kind of apathy - in Poppie's situation - or rebellion and cynicism - in Jesusa's case. Similar to the intent expressed in the Latin American text, the South African text also undermines the patriarchal tradition in various ways. In fact, Van der Merwe (1992:75) identifies three levels of subversion: "deur die hoofkarakter Poppie,

21 Van der Merwe (1992:72) describes Poppic's situation as emblematic of the black race but does not see its implications for her as a black woman. 
deur die verteller wat vir Poppie ondersteun en deur die vroulike outeur, wat die 'dominant' manlike terrein van die politiek betree".

\section{Conclusion}

By acting as facilitators, Poniatowska and Joubert have managed to expose the ironic edge inherent in testimonial writing. Even if the 'victim' is not aware of the irony of her situation, the facilitator can contrive to articulate it through the fictional dimension. As Lenta (1984:153) suggests:

Poppie, however, not only does not relate her experience to the whole social context, but she does not really protest; she cannot, since to do so would be to be possessed of the concepts needed to judge a system which deals unfairly with her. The reader therefore must register that what she suffers is appallingly unjust and must articulate her protest for her.

This unconscious irony is supplemented in the picaresque by the 'victim's' conscious awareness of irony, a factor which makes Hasra no verte Jestís mio so difficult to classify as a mode. 22 Although it has all the features of Joubert's work, it is also a typical picaresque tale with a touch of magical realism exemplified in Jesusa's visions of reincamation where she is fumished with a tail and crown (Poniatowska, 1984:11).

Contemporary autobiographical writings by women exhibit a strong element of social critique as an indictment of political and personal oppression. They assume a political character by asserting a certain commonality in female experience, which can be clearly perceived in comparative literature. The texts discussed above manifest the characteristics of biographies but the conscious participation of both Jesusa and Poppie as active first-person narrators transmutes them into (auto)biographies. Furthernore, their uncertain existence on the periphery of society and the abuse of their basic human rights, endows the protagonists with a picaresque quality which implies a scathing indictment of society.

In conclusion, the main significance of this comparison lies in its affirmation of a feminist 'commonality' and the part it plays in the political collective. Despite many black and indigenous women's claims to be different from white women, the facilitators in these two texts have illustrated that 'outsiders' can promote a different, less subjective perspective on experience. Consequently, although

22 As a protagonist, Jesusa displays an acutc knowledge of human nature which cnables her to distinguish between appearance and reality in many instances. She is especially awarc of the hypocritical attitudes assumed by government institutions and the church. 
Meese (1990:98) admits that feminism cannot be generalized, she stresses the unlimited potential of comparative literature when she asserts that

Nonetheless, the need to elaborate similarities and differences in the world community of women represents feminism's most compelling human and theoretical project; it is the project required to open Feminism toward the possibility (which can only ever be a possibility) of global feminisms.

\section{References}

Allende, Isabel. 1989. Eva Luna. London: Penguin

Barnet, M. 1986a. La novela testimonio: socio-literatura. In: Jara, R \& Vidal, H. (eds.) Testimonio y literatura. Minneappolis : Prisma. p. 280-302.

Barnet, M. 1986b. Testimonio y communicacion una via hacia la identidad. In: Jara, R. \& Vidal, H. (eds.) Testimonio y literatura. Minneappolis : Prisma. p. 303-314.

Barry, Kathleen. 1989. Biography and the Search for Women's Subjectivity. Women's Studies International Forum, 12 (6): 561-577.

Bloom, Lynn Z. 1991. Autobio history: Modern Mictwfery. In: Neuman, Shirley (ed.) Autobiography and Questions of Gender. London : Frank Cass. p. 12-24.

Coetzee, A. 1979. Review: Die swerfjare van Poppie Nongena. Speak, 6:28-30.

Daymond, Margaret, Jacobs, J.U. \& Lenta, Margaret (eds.). 1984. Momentum: on Recent South African Writing. Pietermaritzburg : University of Natal Press.

Dorfman, A. 1986. Código politico y código literario: el genero testimonio en Chile hoy. In Jara, R. \& Vidal, H. (eds.). Testimonio y literatura. Minneapolis : Prisma. p. 170-234.

Felski, Rita. 1989. Beyond Feminist Aesthetics: Feminist Literature and Social Change. Cambridge, Mass. : Harvard University Press.

Fernández Olmo, Margarita. 1981. El genero testimonial: aproximaciones femenistas. $R e-$ vista Interamericana, 11 (1):69-75.

Friedman, Susan Stanford. 1988. Women's Autobiographical Selves: Theory and Practice. In: Benstock, Shari (ed.). The Private Self: Theory and Practice in Women's Autobiographical Writings. London : Routledge. p. 34-62.

Gordimer, Nadine. 1987. A Sport of Nature. Cape Town : David Philip.

Haggis, Jane. 1990. Gendering Colonialism or Colonising Gender? Recent Women's Studies Approaches to White Women and the History of British Colonialism. Women's Studies International Formm, 13:105-115.

Hancock, J. 1983. Elena Poniatowska's Hasta no verte Jesiis mio: the Remaking of the Image of Woman. Hispamia: a Journal Devoted to the Interests of the Teaching of Spanish and l'orruguese, 66 (3):353-359.

Hardy, T. 1978. Tess of the d'Urbervilles: A Pure Woman. London : Penguin.

Jara, R. \& Vidal, H. (eds.) 1986. Testimomio y literatura. Minneapolis : Prisma.

Jorgensen, Beth. 1988. Perspectivas femeninas en Hasta no verte, Jesis mio y la flor de lis'. Texto critico, 14 (39): 110-123

Joubert, Elsa. 1978. Die swerfjare van Poppie Nongena. Kaapstad : Tafelberg.

Joubert, Elsa. 1984. [No title]. In: Daymond et al. 1984. Momentum: on Recent South African Writing. Pietermaritzburg : University of Natal Press.

Kushigian, Julie. 1987. Transgresión de la autobiografia y el Bildungsroman en Hasta no verte Jesis mio. Revista iberoamericana, 53 (140):667-677.

Kuzwayo, Ellen. 1987. Call Me Woman. Johannesburg : Ravan. 
Lagos-Pope, Maria Inés. 1990. El testimonio creativo de Hasta no verte Jesús mio. Revista iberoamericana, 56 (150):243-253.

Lejeune, P. 1975. Le pacte antobiographique. Paris : Seuil.

Lemaitre, Monique. 1985. Jesusa Palancares y la dialectica de la emancipación femenina. Revista iberoamericana, 51 (132-133):751-763.

Lenta, Margaret. 1984. A Break in the Silence: The Long Journey of Poppie Nongena. In: Daymond, et al. Momentum: on Recent South African Writing. Pietermaritzburg : University of Natal Press. p. 147-158.

López González, Aralia, Malagamba, Amelia \& Urrutia, Elena (eds.). 1990. Mujer y literatura mexicana y chicana: culturas en contacto, II. Mexico city; Tijuana : Colegio de Mexico.

Meese, Elizabeth. 1990. (Ex)tensions: Re-figuring Feminist Criticism. Urbana : University of Illinois Press.

Menchú, Rigoberta. 1985. Me llamo Rigoberta Menchi y asi me nacio la conciencia. Madrid : Siglo Veintiuno Editores.

Minc, Rose S., (ed.). 1982. Literatures in Transition: the Many Voices of the Caribbean Area. A symposium Gaithersburg, MD : Hispamerica.

Newton, Judith \& Rosenfelt, Deborah (eds.). 1985. Feminist Criticism and Social Change: Sex, Class and Race in Literature and Culture. New York: Methuen.

Ntantala, Phyllis. 1992. A Life's Mosaic: the Autobiography of Phyllis Ntantala Cape Town : David Philip.

Olsen, Tillie. 1980. Silences. London: Virago

Personal Narratives Group (ed.). 1989. Imterpreting Women's Lives: Feminist Theory and Personal Narratives. Bloomington : Indiana University Press.

Poniatowska, Elena. 1984. Hasta no verte Jesuis mio. Madrid: Alianza. First ed. 1969.

Prada Oropeza, R. 1986. De lo testimonial al testimonio: notas para un deslinde del discursotestimonio. In: Jara, R. \& Vidal, H. Testimonio y literatura. Minneapolis : Prisma. p. 7-21

Prell, Riv-Ellen. 1989. The Double Frame of Life History in the Work of Barbara Myerhoff. Personal Narratives Group, 241-258.

Roses, Lorraine Elena. 1981-82. Entrevista con Elena Poniatowska. Plaza: Revista de Literatura, 5-6:51-64,

Scott, Joan. 1988. Deconstructing Equality-versus-difference: or, the Uses of Poststructuralist Theory for Feminism. Feminist Studies, 14 (1):33-50.

Starcevik, Elizabeth D. 1982. Breaking the Silence: Elena Poniatowska a Writer in Transition. In: Minc, Rose S. (ed.) Literatures in Transition: the Many Voices of the Caribbean Area. A symposium. Gaithersburg, MD : Hispamerica. p. 63-68.

Van der Merwe, C.N. 1992. Poppie Nongena - realisme of sosiale diskoers? New contrast, 20 (2):70-76.

Wenzel, Marita. 1993. Gordimer's Rendition of the Picaresque in A Sport of Nature. Literator, 14 (1):47-63. 